\title{
Description using ultramorphological techniques of the infection of Beauveria bassiana (Bals.-Criv.) Vuill. in larvae and adults of Atta sexdens (Linnaeus, 1758) (Hymenoptera: Formicidae) Descrição utilizando técnicas ultramorfológicas da infecção por Beauveria bassiana (Bals.-Criv.) Vuill. em larvas e adultos de Atta sexdens (Linnaeus, 1758) (Hymenoptera: Formicidae)
}

\author{
Raphael Vacchi Travaglini (D) | Luiz Carlos Forti (D) | Andre Arnostill (D) | Luis Eduardo Pontes Stefanellil (D) \\ Allan Roberto Fernandes Ferreirall! | Roberto da Silva Camargo' (1) | Maria Izabel Camargo-Mathias" (1) \\ Universidade Estadual Paulista. Botucatu, São Paulo, Brasil \\ "Universidade Estadual Paulista. Rio Claro, São Paulo, Brasil \\ I'IFundação Hermínio Ometto. Araras, São Paulo, Brasil
}

\begin{abstract}
Leaf-cutting ants, whose name comes from the habit of cutting leaves and other parts of plants, are dominant herbivores in the Americas, attacking different crops to keep symbiotic fungi (their main food source) in the colony. These ants are soil inhabitants, an environment rich in microorganisms, many of which are considered entomopathogenic. In order to describe a kind of microbial biological control of these ants through histological techniques, we used the fungus Beauveria bassiana (Bals.- Criv.) Vuill. Larvae and adult workers of Atta sexdens (Linnaeus, 1758) were exposed to a fungal suspension with the concentration of $106 / \mathrm{conidia} / \mathrm{mL}$. The specimens were adequately prepared to describe the behavior of the fungus on the integument at 24, 48 and 72 hours after initial exposure. Some specimens were used to represent these periods, being properly processed for scanning electron microscopy, which was applied to document the fungus development on the surface of the insect integument. To better understand the dynamics of the fungal infection, from the conidial adhesion to the potential colonization of the insides of the insect, the histological technique with $\mathrm{HE}$ staining was applied. The results showed that, in immature individuals, the hyphal penetration of $B$. bassiana fungi into the insect integument occurred in $48 \mathrm{~h}$.
\end{abstract}

Keywords: Leaf-cutter ants. Immature. Biological control. Entomopathogenic fungi.

Resumo: As formigas cortadeiras, cujo nome deriva do hábito de cortar folhas e outras partes de plantas, são herbívoros dominantes nas Américas, atacando diferentes culturas para manter o fungo simbiótico (principal fonte de alimento) na colônia. Habitam o solo, ambiente rico em microorganismos, muitos dos quais são considerados entomopatogênicos. Para descrever um tipo de controle biológico microbiano nessas formigas, através de técnicas histológicas, utilizou-se o fungo Beauveria bassiana (Bals.-Criv.) Vuill., aplicado em larvas e trabalhadores adultos de Atta sexdens (Linnaeus, 1758), que foram expostos a uma suspensão de fungos com a concentração de 106 conídios $/ \mathrm{mL}$. Foram adequadamente preparados para descrever o comportamento do fungo no tegumento às 24, 48 e 72 horas após a exposição inicial. Alguns indivíduos foram utilizados para representar esses períodos, sendo processados adequadamente para realizar a técnica do microscópio eletrônico de varredura para documentar o desenvolvimento do fungo na superfície do tegumento do inseto. Para entender melhor a dinâmica da infecção fúngica, desde a adesão dos conídios até a potencial colonização no interior do inseto, foi aplicada a técnica histológica com coloração com HE. Os resultados mostraram que, em indivíduos imaturos, a penetração das hifas de $B$. bassiana no tegumento do inseto ocorreu em $48 \mathrm{~h}$.

Palavras-chave: Formiga cortadeira. Imaturos. Controle biológico. Fungo entomopatogênico.

TRAVAGLINI, R. V., L. C. FORTI, A. ARNOSTI, L. E. P. STEFANELLI, A. R. F. FERREIRA, R. S. CAMARGO \& M. I. CAMARGO-MATHIAS, 2020. Description using ultramorphological techniques of the infection of Beauveria bassiana (Bals.-Criv.) Vuill. in larvae and adults of Atta sexdens (Linnaeus, 1758) (Hymenoptera: Formicidae). Boletim do Museu Paraense Emílio Goeldi. Ciências Naturais 15(1): 101-111. DOI: http://doi.org/10.46357/bcnaturais.v15i1.201.

Autor para correspondência: Raphael Vacchi Travaglini. Universidade Estadual Paulista. Faculdade de Ciências Agronômicas. Departamento de Proteção de Plantas. Fazenda Lageado, 1780. Rua Dr. José Barbosa de Barros - Jardim Paraíso. Botucatu, SP, Brasil. CEP 18610-034 (raphaelvacchitravaglini@gmail.com).

Recebido em 16/10/2019

Aprovado em 28/02/2020

Responsabilidade editorial: Rony Peterson Santos Almeida
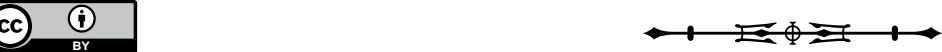


\section{INTRODUCTION}

The leafcutter ants of the genus Atta, popularly known as saúvas, are considered important agriculture pests, defoliating crops and causing losses to livestock breeding and silviculture (Della Lucia \& Vilela, 1993, p. 262). Although there are several strategies and control methods in the literature (Zanetti et al., 2014), chemical bait granules are currently the most widely used (Britto et al., 2016). This method, despite being practical and efficient, presents inconveniences, such as the contamination of the environment and the release of toxic agents that can directly affect human health when misapplied (Boaretto \& Forti, 1997; Loureiro \& Monteiro, 2005). In addition, the forest certification entities have limited the exportation of products with proven toxicity, this fact stimulates the development of studies aiming to find efficient and, at the same time, sustainable methods to control pest insects, as is the case of biological control (Isenring \& Neumeister, 2010; Ribeiro et al., 2012), although this issue was overcome in the last Stockholm convention to persistent organic pollutants.

The fact is that several laboratory studies realized look for mortality and virulence by entomopathogenic fungal species and the results are encouraging in this level. As an example, the pathogenic potential of many species of fungus Beauveria bassiana and Metarhizium anisopliae Metsch have caused death when applied on workers and soldiers of Atta sexdens and Atta bisphaerica Forel, 1908 ants to foster a biological control (Alves \& Sosa-Gómes, 1983; Castilho et al., 2010; Travaglini et al., 2016).

Tests investigating the action of microorganisms to combat leaf-cutter ants have provided different results, depending on the caste and application method (DiehlFleig et al., 1988). According to Alves (1998, p. 1163), the insect infection occurs via integument, including the natural openings, noting that the entomopathogenic fungi infect different developmental stages of the insects (egg, larva, pupa and adult), a useful characteristic in matters of control. According to Arnosti et al. (2016, 2019) and Travaglini et al. (2016), who studied Diaphorina citri Kuwayama
(Hemiptera: Liviidae) exposed to the fungus Isaria fumosorosea ESALQ-1296, and leaf-cutter ants exposed to several fungi, respectively, the conidia adhesion site on the insect's body would directly influence the germination success.

Other studies using entomopathogenic fungi for biological control showed that proteases enzymes, aminopeptidases, esterases and chitinases would be produced in large amounts by M. anisopliae and B. bassiana (St. Leger et al., 1986). These enzymes would modify the structure of the integument in grasshoppers, allowing the hypha to penetrate the insect's body (Bidochka \& Small, 2005, p. 28-50).

Thus, considering these data and aiming to investigate efficient and sustainable strategies to control the proliferation of leaf-cutter ants (important agriculture pests), the present study had the objective to demonstrate, through histological techniques, documenting in pictures the $B$. bassiana development on surface of the insect integument both larvae (immature) and workers (adults) of $A$. sexdens for showing the penetration of fungus hyphae, and how the structural organization and the morphophysiology of the integument would be affected.

\section{MATERIALS AND METHODS}

\section{COLLECTION OF A. sexdens LARVAE AND WORKERS}

The larvae and forager workers of $A$. sexdens used in this experiment were obtained from the colony of the Laboratory of Social-Pest Insects, located in Fazenda Experimental Lageado of the Agronomic Sciences Faculty - UNESP-Botucatu, SP, Brazil, latitude (22 50' 48" S), longitude (48 26' $\left.06^{\prime \prime} \mathrm{W}\right)$ and altitude $(817,74 \mathrm{~m})$, according to the methodology proposed by Forti et al. (1994), and maintained under controlled conditions (Relative humidity \% $75 \pm 10$, Temperature ${ }^{\circ} \mathrm{C} 25 \pm 2$ ). Annually the ants' queens are collected after the nuptial flight or three months after this period, already with some workers and a fragment of the symbiont fungus, with shovels and spoons and put in containers, where they are 
transported from the field to the laboratory and continue to receive daily care and fed with leaves.

\section{COLLECTION OF Beauveria bassiana ISOLATE}

The isolated fungi used in this study were collected from $A$. sexdens dead queens from the Laboratory of Fungal Ecology and Systematics (Laboratório de Ecologia e Sistemática de Fungos - LESF), placed on São Paulo State University (UNESP), Institute of Biosciences, Rio Claro, SP, Brazil. After inoculation, the isolates were multiplied in 5-cm Petri dishes containing malt agar (2\%), covered with plastic film and maintained in Biochemical Oxygen Demand (BOD) (temperature $\pm 25^{\circ} \mathrm{C}$ ), for fifteen days, the period of time needed for the emergence of conidia. Serial transfer was performed 15 days after inoculation.

\section{PREPARATION OF THE SUSPENSION TO}

\section{APPLY B. bassiana}

To prepare the suspension, $10 \mathrm{~mL}$ of distilled water + Tween $80 \AA$ at $0.001 \%$ were added to one of the Petri dishes. Then, the conidia were counted in a Neubauer chamber under bright field light microscope to obtain the concentration of $10^{6} \mathrm{conidia} / \mathrm{mL}$. For exposure of individuals to the suspension of conidia, the fungus $B$. bassiana replicated in petri dishes each 15 days were removed from its culture PDA+ malt agar (2\%), as previously described and adjusted to $10^{6}$ conidia/mL in order to standardize the exposure of individuals isolated in $250 \mathrm{ml}$ plastic containers or Petri dishes, in the larvae case, which were removed in different time periods of 24, 48 and 72 hours, and fixed in paraformaldehyde (4\%) for monitoring with the use of different ultramorphological techniques Scanning Electron Microscopy (SEM) and hematoxylin and eosin $(\mathrm{HE})$ as described in the sequence.

\section{PATHOGENICITY BIOASSAYS WITH WORKERS (ADULT)}

The worker ants were classified according to the cephalic capsule measurement $2 \mathrm{~mm}$ and individually immersed for three seconds in the fungal suspensions using entomological tweezers, according to the protocol described by Loureiro \& Monteiro (2005). After, the ants were transferred to plastic pots $(250 \mathrm{~mL})$ containing cotton wetted with water. Two groups were stablished for the bioassays: a control group, formed by individuals not exposed to the fungus; i.e., immediately fixed for the application of the histological techniques and SEM after being collected; and treatment group, comprising the workers exposed to the fungal suspension for 24,48 and 72 hours.

\section{PATHOGENICITY BIOASSAYS WITH LARVAE (IMMATURE)}

Larvae of $A$. sexdens were topically exposed to the fungal suspension (10 conidia/mL), using a micropipette $(1 \mu \mathrm{L})$ according to the protocol described by Broome et al. (1976). After the exposure, the larvae were transferred to sterile Petri dishes covered with wetted filter paper and maintained at $25{ }^{\circ} \mathrm{C}$ in the laboratory environment (Laboratório de Insetos Sociais-Praga - LISP). After 24, 48 and 72 hours, three individuals from each time interval were collected and sent to the histological and SEM procedures. The control larvae (without contact with the fungus) were collected, immediately fixed, and sent to histological and SEM analyses.

\section{HISTOLOGY}

In the laboratory of the Brazilian Central of Studies on Ticks Morphology (BCSTM), IB-UNESP-Rio Claro, SP, Brazil, nine larvae and nine workers were collected alive, anesthetized by fridge thermal shock and fixed in paraformaldehyde (4\%) for seven days and dehydrated in crescent ethanol series at 70\%, 80\%, 90\% and 95\% (4 baths/15 minutes each). Then, the samples were embedded and included using Leica historesin in plastic molds. The blocks were polymerized and placed in wooden stands to be sectioned using microtome Leica (3- $\mu$ m thickness). Posteriorly, the sections were transferred to glass slides and stained with hematoxylin and eosin (HE) (Junqueira \& Junqueira, 1983, p. 123). The same procedure was performed with larvae and workers exposed to the suspension. 


\section{SCANNING ELECTRON MICROSCOPY}

For the application of this technique, three workers were collected from each treatment group. The whole specimens were fixed in paraphormaldehyde $4 \%$ for 15 days and in phosphate potassium buffer at $0.05 \mathrm{M}$ and $\mathrm{pH} 7.4$ for 24 hours. Then, the samples were dehydrated in crescent series (70\%, 80\%, 90\% and 95\%) of acetone and water solution for five minutes each bath and dried at critical point. The material was attached with double-sided tape to aluminum stubs in three different positions - dorsal, left lateral and right lateral, metallized for four minutes with gold $(70 \mathrm{~mA})$ in sputtering with a metallizer brand Bal-Tec, model SCD 050 (110V, 50/60 Hz and 1 phase) and taken for analysis and photo documentation under scanning electron microscope Hitachi TM 3000 (Hitachi High-Technologies Corporation/Japan) operated at $15 \mathrm{kV}$ in the Electron Microscopy Laboratory of the Bioscience Institute, UNESP-Rio Claro, SP, Brazil.

\section{RESULTS}

The results of the present study show the dynamics of adhesion, germination and penetration of the fungus $B$. bassiana in the integument of $A$. sexdens larvae and workers in different developmental stages (immature and adult).

\section{AFTER 24 HOURS}

The SEM technique showed that both the larvae and the workers presented conidia adhered to the integument, mainly in the region next to the buccal cavity, which presents a sculptured cuticle, and grooves, in addition to the junction of articulated mouthparts (mandible/clypeus) (Figures 1B and 2B), allowing the conidia to gather and attach.

Although preferably adhered to the buccal region, some conidia could be observed throughout the body of larvae and workers; however, only few (one or two images of our gallery) were starting the germination process.

The histological analysis confirmed these results; the conidia were adhered to the cuticle. With specific regard to the larvae, some regions of the body showed groups of conidia adhered and some of them were in the initial phase of germination, because it is not in a globose pattern (Figure 1E), differently from the workers, where only adhesion was observed (Figure 2E).

\section{AFTER 48 HOURS}

After 48 hours of exposure, the SEM revealed that, in the larvae, groups of conidia remained adhered in many regions of the integument and throughout the body; additionally, many of them were germinating, which was confirmed by the observation of the germ tube, structure of the fungus that originates the hyphae (Figure 1C). The histological analysis showed that the integument of the larvae had been penetrated by the hyphae (Figure 1F).

Differently from the larvae, only some conidia presented germ tubes in the workers (Figure 2C).

The histological sections showed, mainly in the thorax region the deposition of conidia in the integumentary grooves, where exocrine glands openings are found (Figure 2F).

\section{AFTER 72 HOURS}

In the period of 72 hours after exposure, the surface of the integument of the larvae was totally covered by hyphae (SEM) (Figure 1D), indicating that this treatment was completely favorable for the development of the fungus. The histological analysis of the larvae demonstrated that the entomopathogenic fungus hypha were able to colonize the surface of the integument and overcome the cuticle barrier, reaching the interior of the body (Figure 1G).

For the workers, the SEM showed that the conidia were adhered (only some germinated) to the surface of the integument. The histology, however, showed that the interior of the workers' body was totally colonized by hyphae. The analysis of the pronotum region of one of the workers, showed the histological moment when the hyphae overcame the barrier of the integument, penetrating and colonizing the interior of the insect (Figure 2G).

For better understanding and comparison, the results are summarized in Table 1. 

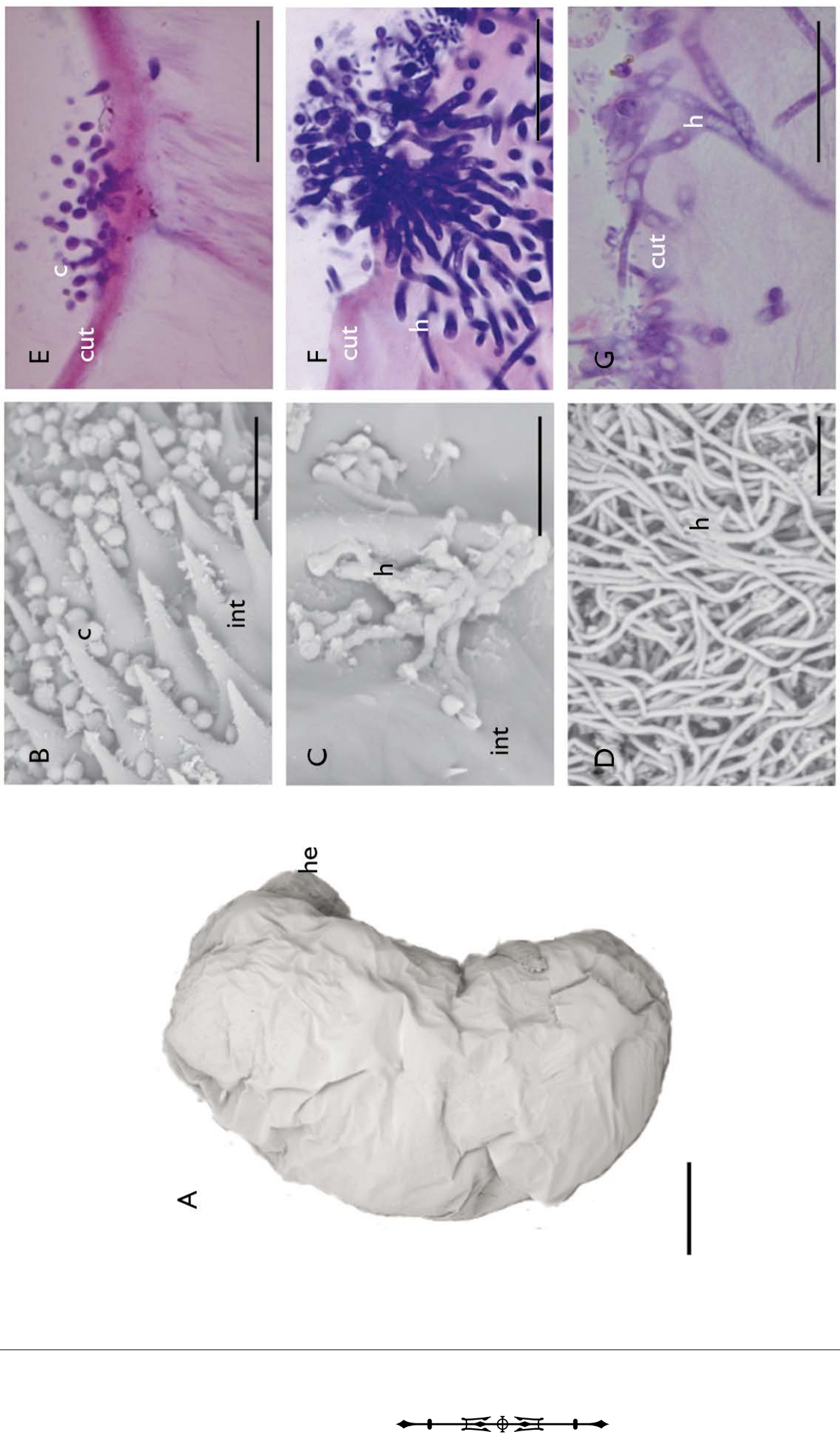

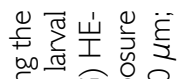

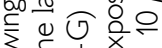

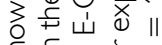

它. $\frac{1}{\mathrm{c}}$

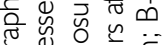

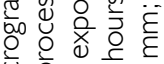

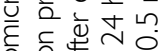

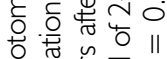

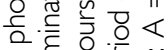

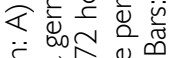

它

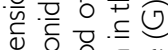

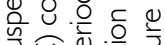

气徬黄

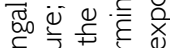

ङ

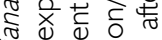

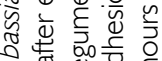

(ब)

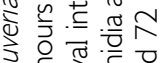

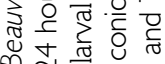

$\infty \underset{0}{4} \frac{\pi}{0}$

प 0

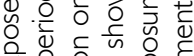

x ․ㅡㄹ

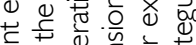
ब.

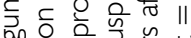

列.

.气

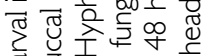

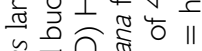

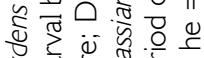

จำ

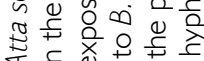

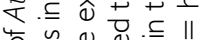

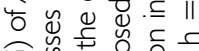

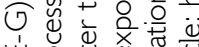

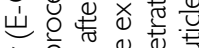

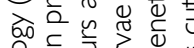

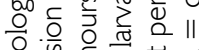

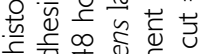

प्र

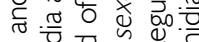

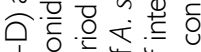

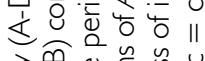

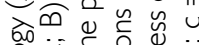

잉

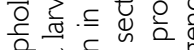

흔

है

낙 중

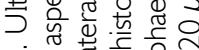

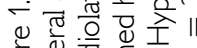

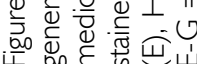




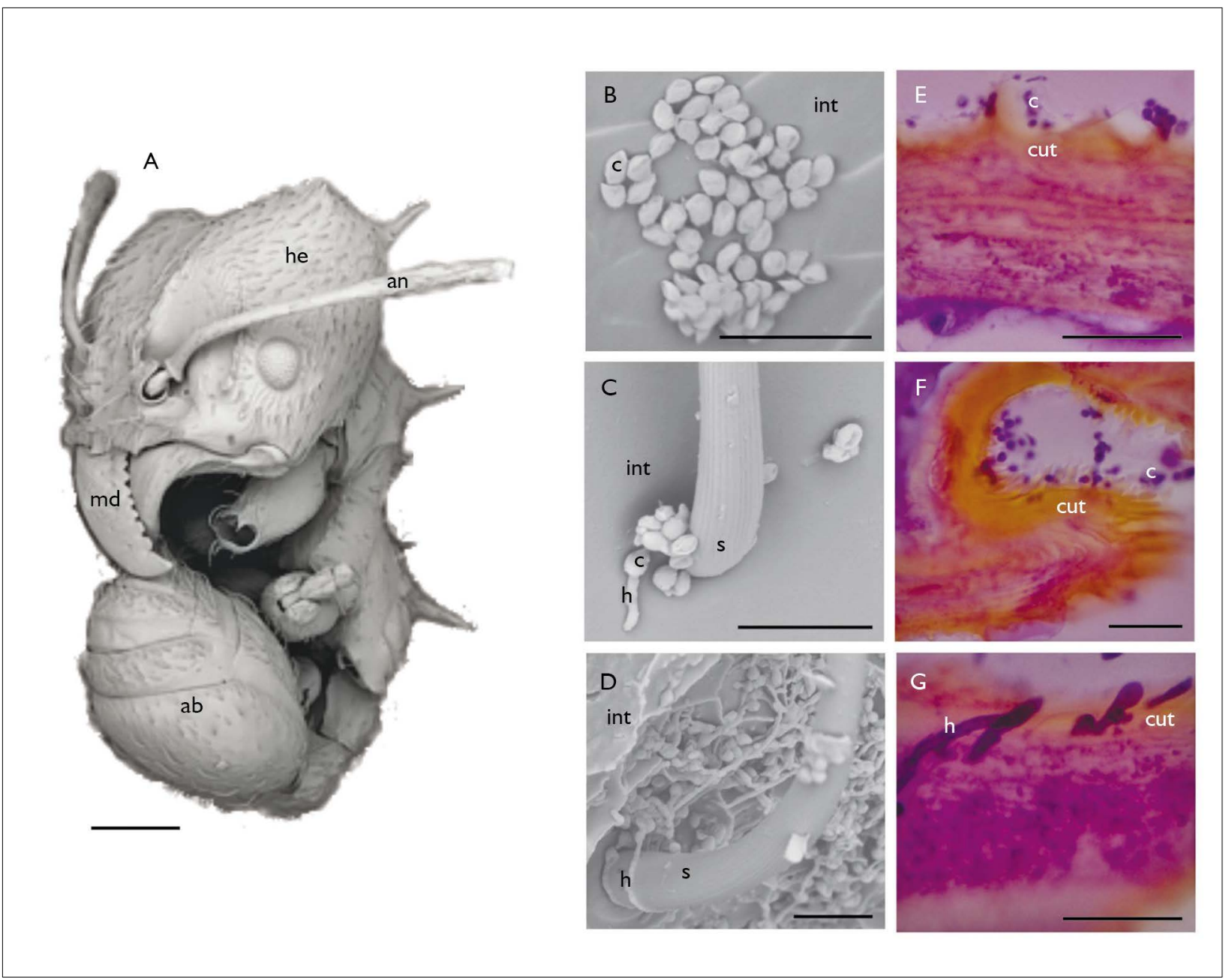

Figure 2. Ultramorphology (A-D) and histology (E-G) of Atta sexdens worker integument exposed to Beauveria bassiana fungal suspension: A) photomicrograph showing the general aspect of a worker; B) conidia adhesion processes in the worker integument in the period of 24 hours after exposure; C) conidia germination processes in the worker torax region in the period of 48 hours after the exposure; D) Hyphae proliferation on the worker integument in the period of 72 hours after exposure; $\mathrm{E}-\mathrm{G}$ ) HE-stained histological sections of $A$. sexdens worker exposed to B. bassiana fungal suspension, showing: conidia adhesion in the period of 24 hours after exposure (E), conidia adhesion in the torax region integument in the period of 48 hours after exposure (F), and Hyphae proliferation on the worker integument 72 hours after exposure (G). Bars: $A=0.5$ mm; B-D $=10 \mu \mathrm{m} ; \mathrm{E}-\mathrm{G}=20 \mu \mathrm{m}$. Legends: an = antennae; $\mathrm{ab}=$ abdomen; $\mathrm{c}=$ conidia; cut $=$ cuticle; $\mathrm{h}$ $=$ hypha; he = head; int = integument; $\mathrm{md}=$ mandible; $\mathrm{s}=$ sensilla.

Table 1. Summary of the dynamics of adhesion (a), germination $(\mathrm{g})$ and penetration $(\mathrm{p})$ of $B$. bassiana conidia and hypha in suspension on the integument of larvae and adult workers of $A$. sexdens ants 24, 48 and 72 hours after exposure.

\begin{tabular}{c|c|c|c|c}
\hline & \multicolumn{2}{|c|}{ Larvae } & \multicolumn{2}{c}{ Workers } \\
\hline Exposure time & SEM & Histology & SEM & Histology \\
\hline $24 \mathrm{~h}$ & $\mathrm{a}$ & $\mathrm{a}$ & $\mathrm{a}$ & $\mathrm{a}$ \\
\hline $48 \mathrm{~h}$ & $\mathrm{~g}$ & $\mathrm{p}$ & $\mathrm{g}$ & $\mathrm{a}$ \\
\hline $72 \mathrm{~h}$ & $\mathrm{~g}$ & $\mathrm{p}$ & $\mathrm{g}$ & $\mathrm{p}$ \\
\hline
\end{tabular}

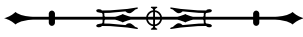




\section{DISCUSSION}

The search for efficient and, at the same time, sustainable to control pest insects is ongoing, once their proliferation causes important damages to the agriculture in general and significant economic losses (Della Lucia et al., 2014; Montoya-Lerma et al., 2012; Zanetti et al., 2014), suggesting the search for new control alternatives.

The present study describes the conidia adhesion and germination potentials, as well as the penetration of $B$. bassiana hyphae in the integument of larvae and workers of A. sexdens ants, taking into consideration the time needed for these processes to occur in the laboratory (Figures 1 and 2). Mortality tests have already been reported (Travaglini et al., 2016; Travaglini, 2017), the focus of this study was to describe the development of the fungus in the body structures of immature and adult $A$. sexdens in order to validate this type of control, however, it is clear the greater susceptibility of the larvae in relation to workers due to the latter's ability to promote its own cleaning and even removal of the microbial agent in this study, after SEM and Histology methodology, the results also suggest that some parts of the body provide better development for the entomopathogenic fungus (greater accumulation of conidia or less time for the germination and penetration of the hyphae), for example, mouthparts and connective tissue between adult joints, which provides a basis for future studies in the area of application technology (Figure 3).

Diehl-Fleig et al. (1988), studied $A$. sexdens soldiers and reported that, for these ants, the period of 72 hours of exposure to entomopathogenic fungi would present a mortality rate of $50 \%$ in a controlled environment. Castilho et al. (2010) reported the virulence of $M$. anisopliae, with a mortality rate of $80 \%$ of the soldiers in the first 72 hours after inoculation in $A$. bisphaerica and, also that $B$. bassiana isolates were pathogenic for $A$. sexdens in this same period of time.

In this study, the penetration of $B$. bassiana hypha in the body of $A$. sexdens larvae occurred in less than 48 hours, probably due to fragile constitution of the exoskeleton in this life cycle, when the cuticle is not fully sclerotized, very
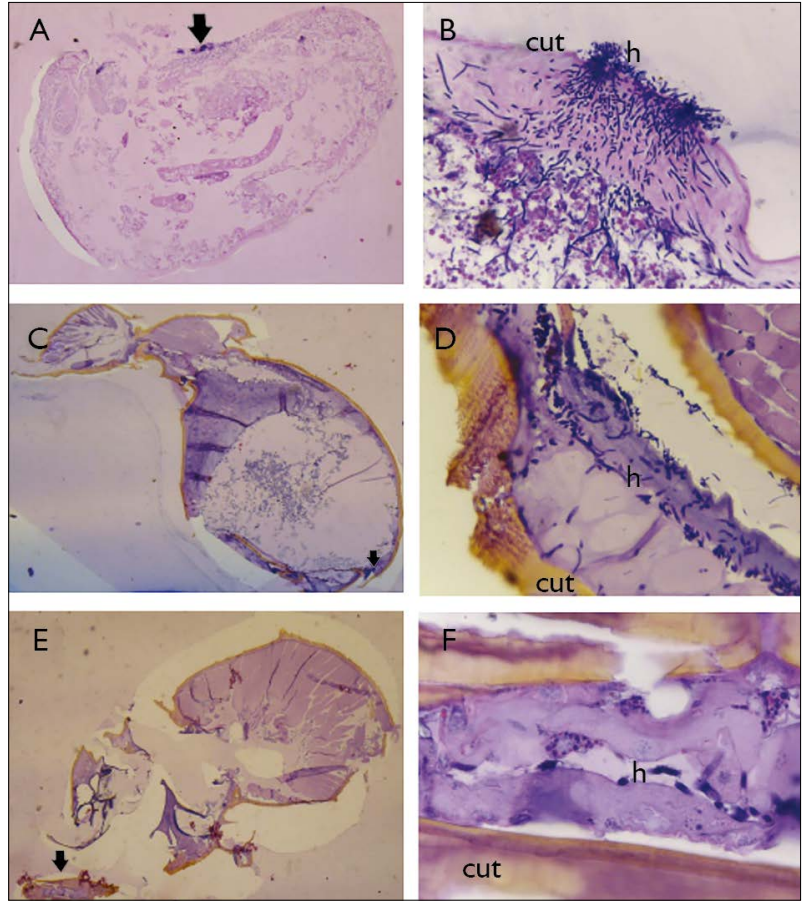

Figure 3. Complement: A) Overview of larva in historesin (HE); B) Hyphae penetrating the larval cuticle (A); $C$ ) general view of the worker abdomen in historesin (HE); D) Hyphae penetrating inside the gaster (C); E) worker head included in historesin (HE); F) Hyphae inside the mandible $(E)$. Legends: $h=$ Hyphae; cut = cuticle. $A, C$ and $E 4 x, B$ and $D 40 x$ and $F$ 100x objective lens.

relevant information for this kind of control. For the adults, the presence of sensilla probably facilitated the adhesion of conidia in these structures, the penetration occurred within 72 hours, which was expected, once the integument in this phase is fully sclerotized, providing the insect with protection against desiccation, parasitism and predation, acting as an efficient physical protection barrier (Chapman, 1998, p. 770). It is important to note that the application was targeted and adjuvants may have accelerated the process (Travaglini et al., 2016; Arnosti et al., 2019).

Other studies were developed to investigate what would be the more appropriate time for the conclusion of each step (adhesion, germination and penetration), which would lead to the success of entomopathogenic fungi in the control of pest insects. Moino et al. (2002), who studied underground termites Heterotermes tenuis Hagen, 1858

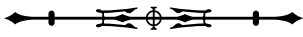


(Isoptera, Rhinotermitidae) using SEM techniques, found that the exposure to B. bassiana and M. anisopliae conidia would cause important modifications to the surface of the insect in the moments of adhesion and germination. These conidia would need approximately 24 hours for germination and 48 hours for penetration, corroborating our results for the larvae analyzed.

An important observation is that the exocrine glands of fully developed adults secret chemical substances that help in the defense against pathogens that represent an obstacle for the application of biological control strategies on ants. The production of antimicrobial secretions synthesized by certain exocrine glands (mainly the metapleural one) has not started in the immature individuals (Bot et al., 2002; Lacerda et al., 2010; Poulsen et al., 2002; Vieira et al., 2012), which facilitates the permanence of conidia on the integument and the penetration of hyphae in the body of these individuals. Workers use their appendages - antennae and legs - to collect detritus and microorganisms from larvae, reserving them in the buccal cavity for posterior elimination (pellet) in the colony waste chamber (Pagnocca et al., 1996; Mueller et al., 2001; Barbieri et al., 2007). The ants have the habit of licking the substrate surface, this behavior allows greater exposure of the immature to the entomopathogenic fungus when present (contact between worker buccal region/larvae), mainly during the feeding process (Petralia \& Vinson, 1978).

With specific regard to the adults, considering the conidia adhesion and germination processes, it is important to consider the cleaning behavior, common in social insect workers, named allogrooming (Hölldobler \& Wilson, 1990, p. 733). This behavior can cause the removal of the conidia from the surface of the insect, even in sites of difficult access, as the clypeus lateral region and the gaster junction (Travaglini et al., 2016). On the other hand, reports in the literature on biological control confirm that a single viable conidium, finding all the favorable conditions to develop, is able to lead the host to death (Arnosti et al., 2016).
In addition to the integument, the natural openings of the insect's body, such as the anus, spiracles and buccal cavity, have been considered important sites for the penetration of entomopathogenic fungi (Kermarrec et al., 1986). These openings would have the protection of anatomical structures that prevent the penetration of strange agents into the insect's body (Dunn, 1986; Silva, 2002). With specific regard to the spiracles, the trachea and tracheoles would act as a barrier. The saliva protects the buccal cavity, in addition to having the potential of inhibiting conidia germination (Rodrigues et al., 2008; FernandezMarin et al., 2006).

Besides to understanding the infection, other necessary information to be studied the way that occur the transmission and dispersion of the microbial agent inside the colony after the pathogen to reach the larvae, which are the most susceptible individual (Travaglini et al., 2017). According to Oi \& Williams (2002), who studyied pathogen transmission, was verified that the queen was contaminated after the introduction of larvae and pupae contaminated by Thelohania solenopsae Knell, Allen \& Hazard, 1996 (Microsporidia: Thelohaniidae) in Solenopsis invicta Buren, 1972 colonies. The same research line, reported crescent dispersion of Vairimorpha invictae Jouvenaz \& Ellis, 1986 (Microsporidia: Burenellidae) among pupae (Oi et al., 2005). Contrarily, Armitage et al. (2016) reported the absence of contamination in Acromyrmex echinatior Wheeler, 1937 pupae exposed to M. anisopliae. Social insects have a high capacity for hygiene and isolation of organisms outside the colony (Cremer et al., 2007, p. 693-702).

The present study confirmed that the conidia adhesion and germination on the cuticle surface of $A$. sexdens adult workers started to occur 24 hours after exposure to the fungus $B$. bassiana, when it was possible to observe the appressoria (penetration structure). The process of mass penetration of $B$. bassiana hyphae occurred 72 hours after the exposure to the fungal suspension, corroborating studies on ticks Rhipicephalus (Boophilus)

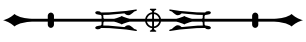


microplus Canestrini, 1888 (Acari: Ixodidae) (Arruda et al., 2005). Still regarding the relation parasite/host, Bittencourt et al. (1999), using scanning electron microscopy, reported that the main way of penetration of $M$. anisopliae in $B$. microplus would be via integument, emphasizing that no evidence of infection via natural openings was found (Bittencourt et al., 1995).

\section{CONCLUSION}

The characteristics of each entomopathogenic fungus (e.g., virulence, time needed for conidia adhesion and germination) must be considered in the development of biological control strategies. Our results lead to the conclusion that the biological control of $A$. sexdens leafcutter ants using the fungus $B$. bassiana should focus the larvae, the biological cycle when the integument is still fragile (less sclerotized), allowing successful adhesion and germination of the fungus. Furthermore, the elimination via immature contamination would directly interfere in the generation of new individuals, affecting the development of the colony and, consequently, the success of the species.

\section{ACKNOWLEDGEMENTS}

All the laboratory technicians, M. Iamonte, A. Teruyoshi Yabuki and G. Mello Souza for the preparation of biological material. This study was financed in part by the Coordenação de Aperfeiçoamento de Pessoal de Nível Superior (CAPES), from Brazil, Finance Code 001.

\section{REFERENCES}

ALVES, S. B., 1998. Controle microbiano de insetos: 4. ed. FEALQ, Piracicaba.

ALVES, S. B. \& D. R. SOSA-GÓMES, 1983. Virulência do Metarhizium anisopliae (Metsch.) Sorok. e Beauveria bassiana (Bals.) Vuill. para castas de Atta sexdens rubropilosa (Forel, 1908). Poliagro 5(1): $1-9$.

ARMITAGE, S. A. O., H. FERNANDEZ-MARÍN, J. J. BOOMSMA \& W. T. WCISLO, 2016. Slowing them down will make them lose: a role for attine ant crop fungus in defending pupae against infections? Journal of Animal Ecology 85(5): 1210-1221. DOI: http://dx.doi. org/10.1111/1365-2656.12543.
ARNOSTI, A., I. DELALIBERA, M. R. CONCESCHI, R. V. TRAVAGLINI \& M. I. CAMARGO-MATHIAS, 2016. Morphological mapping of the integument of adult females of Diaphorina citri Kuwayama, targeting the development of control strategies. International Journal of Advance Agricultural Research 4: 57-64.

ARNOSTI, A., I. DELALIBERA, M. R. CONCESCHI, C. P. D'ALESSANDRO, R. V. TRAVAGLINI \& M. I. CAMARGOMATHIAS, 2019. Interactions of adjuvants on adhesion and germination of Isaria fumosorosea on adults of Diaphorina citri. Scientia Agricola 76(6): 487-493. DOI: http://dx.doi. org/10.1590/1678-992x-2017-0240.

ARRUDA, W., I. LUBECK, A. SCHRANK \& M. H. VAINSTEIN, 2005. Morphological alterations of Metarhizium anisopliae during penetration of Boophilus microplus ticks. Experimental and Applied Acarology 37 : 231-244. DOI: https://doi.org/10.1007/s10493-005-3818-6.

BARBIERI, R. F., L. C. FORTI, R. T. FUJIHARA \& A. A. CARLOS, 2007. Fluxo de corante e inseticida entre operárias de formigas cortadeiras. Arquivos do Instituto Biológico 69: 375-377.

BIDOCHKA, M. J. \& C. SMALL, 2005. Phylogeography of Metarhizium, an insect pathogenic fungus. In: F. E. VEGA \& $M$. BLACKWELL (Ed.): Insect-fungal associations: ecology and evolution: 28-50. Oxford University Press Inc., New York.

BITTENCOURT, V. R. E. P., C. L. MASSARD \& A. F. LIMA, 1995. Dinâmica da infecção do fungo Metarhizium anisopliae (Metschnikoff, 1879) Sorokin, 1883, sobre o carrapato Boophilus microplus (Canestrini, 1887). Revista da Universidade Rural - Série Ciências da Vida 17: 83-88.

BITTENCOURT, V. R. E. P., A. G. MASCARENHAS \& J. L. H. FACCINI, 1999. Mecanismo de infecção do fungo Metarhizium anisopliae no carrapato Boophilus microplus em condições experimentais. Ciência Rural 29(2): 351-354.

BOARETTO, M. A. C. \& L. C. FORTI, 1997. Perspectivas no controle de formigas cortadeiras. Série Técnica IPEF 11(30): 31-46.

BOT, A. N. M., D. ORTIUS-LECHNER, K. FINSTER, R. MAILE \& J. J. BOOMSMA, 2002. Variable sensitivity of fungi and bacteria to compounds produced by the metapleural glands of leaf-cutting ants. Insectes Sociaux 49: 363-370. DOI: https://doi.org/10.1007/ PL00012660.

BRITTO, J. S., L. C. FORTI, M. A. OLIVEIRA, R. ZANETTI, C. F. WILCKEN, J. C. ZANUNCIO, A. E. LOECK, N. CALDATO, N. S. NAGAMOTO, P. G. LEMES \& R. S. CAMARGO, 2016. Use of alternatives to PFOS, its salts and PFOSF for the control of leaf-cutting ants Atta and Acromyrmex. International Journal of Research in Environmental Studies 3: 11-92.

BROOME, J. R., P. P. SIKOROWSKI \& B. R. NORMENT, 1976. A mechanism of pathogenicity of Beauveria bassiana on larvae of the imported fire ant, Solenopsis richteri. Journal of Invertebrate Pathology 28(1): 87-91. DOI: https://doi.org/10.1016/0022-2011(76)90074-4. 
CASTILHO, A. M. C., M. E. FRAGA, E. L. AGUIAR-MENEZE \& C. A. R. ROSA, 2010. Seleção de isolados de Metarhizium anisopliae e Beauveria bassiana patogênicos a soldados de Atta bisphaerica e Atta sexdens rubropilosa em condições de laboratório. Ciência Rural 40(6): 1243-1249. DOI: https://doi.org/10.1590/S010384782010005000100 .

CHAPMAN, R. F., 1998. The insects: structure and function: 4. ed. Cambridge University Press, Cambridge.

CREMER, S., S. A. O. ARMITAGE \& P. SCHMID-HEMPEL, 2007. Social immunity. Current Biology 17(16): 693-702. DOI: https:// doi.org/10.1016/j.cub.2007.06.008.

DELLA LUCIA, T. M. C. \& E. F. VILELA, 1993. Métodos atuais de controle e perspectivas. In: T. M. C. DELLA LUCIA (Ed.): As formigas cortadeiras: 163-190. Folha de Viçosa, Viçosa.

DELLA LUCIA, T. M. C., L. C. GANDRA \& R. N. C. GUEDES, 2014. Managing leaf-cutting ants: peculiarities, trends and challenges. Pest Management Science 70(1): 14-23. DOI: https:// doi.org/10.1002/ps.3660.

DIEHL-FLEIG, E., M. E. SILVA \& M. R. M. PACHECO, 1988. Testes de patogenicidade dos fungos entomopatogênicos Beauveria bassiana e Metarhizium anisopliae em Atta sexdens piriventris (Santschi, 1919) em diferentes temperaturas. Ciência e Cultura 40(11): 1103-1105.

DUNN, P. E., 1986. Biochemical aspects of insect immunology. Annual Review of Entomology 31: 321-339. DOI: https://doi. org/10.1146/annurev.en.31.010186.001541.

FERNANDEZ-MARIN, H., J. K. ZIMMERMAN, S. A. REHNER \& W. T. WCISLO, 2006. Active use of the metapleural glands by ants in controlling fungal infection. Proceedings of the Royal Society B 273(1594): 1689-1695. DOI: https://doi.org/10.1098/ rspb.2006.3492.

FORTI, L. C., D. R. PRETTO \& I. P. GARCIA, 1994. Aprimoramento de metodologias experimentais para controle de formigas cortadeiras. Anais do Curso Atualização no Controle de Formigas Cortadeiras 3: 14-23.

HÖLLDOBLER, B. \& E. O. WILSON, 1990. The ants. Harvard University Press, Cambridge.

ISENRING, R. \& L. NEUMEISTER, 2010. Recommendations regarding Derogations to use alpha-Cypermethrin, Deltamethrin, Fenitrothion, Fipronil and Sulfluramid in FSC Certified Forests in Brazil. In: INSECTICIDES for control of pest insects in FSC Certified Forests in Brazil: recommendations by technical advisors: 1-99. FSC Pesticides Committee, [S. 1.].

JUNQUEIRA, L. C. U. \& L. M. M. S. JUNQUEIRA, 1983. Técnicas básicas de citologia e histologia. Livraria e Editora Santos, São Paulo.
KERMARREC, A., G. FEBUAY \& M. DECHARME, 1986. Protection of leaf-cutting ants from biohazards: is there a future for microbiological control? In: S. LOFGREN \& R. K. VANDER MEER (Ed.): Fire ants and leaf-cutting ants: biology and management: 339-356. Westview Studies in Insect Biology, London.

LACERDA, F. G., T. M. C. DELLA LUCIA, J. E. SERRÃO, P. R. CECON, L. M. SOUZA \& D. J. SOUZA, 2010. Morphometry of the metapleural gland of workers engaged in different behavioral tasks in the ant Atta sexdens rubropilosa. Animal Biology 60(2): 229-236. DOI: https://doi.org/10.1163/157075610X496315.

LOUREIRO, E. S. \& A. C. MONTEIRO, 2005. Patogenicidade de isolados de três fungos entomopatogênicos a soldados de Atta sexdens sexdens (Linnaeus, 1758) (Hymenoptera: Formicidae). Revista Árvore 29(4): 553-561. DOI: https://doi.org/10.1590/ S0100-67622005000400007.

MOINO, J. R. A., S. B. ALVES, R. B. LOPES, P. M. O. J. NEVES, R. M. PEREIRA \& S. A. VIEIRA, 2002. External development of the entomopathogenic fungi Beauveria bassiana and Metarhizium anisopliae in the subterranean termite Heterotermes tenuis. Scientia Agricola 59(2): 267-273. DOI: https://doi.org/10.1590/S010390162002000200010 .

MONTOYA-LERMA, J., C. GIRALDO-ECHEVERRI, I. ARMBRECHT, A. FARJI-BRENER \& Z. CALLE, 2012. Leaf-cutting ants revisited: towards rational management and control. Journal International Journal of Pest Management 58(3): 225-247. DOI: https://doi.or g/10.1080/09670874.2012.663946.

MUELLER, U. G., T. SCHULTZ, C. R. CURRIE \& D. MALLOCH, 2001. The origin of the attineant-fungus mutualism. The Quarterly Review of Biology 76(2): 169-197.

OI, D. H. \& D. F. WILLIAMS, 2002. Impact of Thelohania solenopsae (Microsporidia: Thelohaniidae) on Polygyne colonies of red imported fire ants (Hymenoptera: Formicidae). Journal of Economic Entomology 95(3): 558-562. DOI: https://doi.org/10.1603/00220493-95.3.558.

OI, D. H., J. A. BRIANO, S. M. VALLESA \& D. F. WILLIAMS, 2005. Transmission of Vairimorpha invictae (Microsporidia: Burenellidae) infections between red imported fire ant (Hymenoptera: Formicidae) colonies. Journal of Invertebrate Pathology 88(2): 108-115. DOI: https://doi.org/10.1016/j.jip.2004.11.006.

PAGNOCCA, F. C., S. C. CARREIRO, O. C. BUENO, M. I. HEBLING \& O. A. SILVA, 1996. Microbiological changes in the nests of leaf-cutting ants fed on sesame leaves. Journal of Applied Entomology 120(1-5): 317-320. DOI: https://doi. org/10.1111/j.1439-0418.1996.tb01612.x.

PETRALIA, R. S. \& S. B. VINSON, 1978. Feeding in the larvae of the imported fire ant, Solenops isinvicta: behavior and morphological adaptations. Annals of the Entomological Society of America 71(4): 643-648. DOI: https://doi.org/10.1093/aesa/71.4.643.

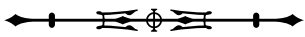


POULSEN, M., A. N. M. BOT, M. G. NIELSEN \& J. J. BOOMSMA, 2002. Experimental evidence for the costs and hygienic significance of the antibiotic metapleural gland secretion in leaf-cutting ants. Behavioral Ecology and Sociobiology 52: 151-157. DOI: https:// doi.org/10.1007/s00265-002-0489-8.

RIBEIRO, M. M. R., K. D. AMARAL, V. E. SEIDE, B. M. R. SOUZA, T. M. C. DELLA LUCIA, M. C. M. KASUYA \& D. J. DE SOUZA, 2012. Diversity of fungi associated with Atta bisphaerica (Hymenoptera: Formicidae): the activity of Aspergillus ochraceus and Beauveria bassiana. Psyche 2012: 389806. DOI: https://doi. org/10.1155/2012/389806.

RODRIGUES, A., C. D. CARLETTI, O. C. BUENO \& F. C. PAGNOCCA, 2008. Leaf-cutting ant faecal fluid and mandibular gland secretion: effects on microfungi spore germination. Brazilian Journal of Microbiology 39(1): 64-67. DOI: https://doi.org/10.1590/ S1517-83822008000100016.

SILVA, C. C. A., 2002. Aspectos do sistema imunológico dos insetos. Biotecnologia, Ciência e Desenvolvimento 24: 68-72.

ST. LEGER, R. J., A. K. CHARNLEY \& R. M. COOPER, 1986. Cuticledegrading enzymes of entomopathogenic fungi: synthesis in culture on cuticle. Journal of Invertebrate Pathology 48(1): 85-95. DOI: https://doi.org/10.1016/0022-2011(86)90146-1.
TRAVAGLINI, R. V., 2017. Bases para o controle microbiano de formigas cortadeiras. Tese (Doutorado em Proteção de Plantas) Universidade Estadual Paulista "Júlio de Mesquita Filho", Botucatu.

TRAVAGLINI, R. V., L. C. FORTI, A. ARNOSTI, R. S. CAMARGO, L. C. SILVA \& M. I. CAMARGO-MATHIAS, 2016. Mapping the adhesion of different fungi to the external integument of Atta sexdens rubropilosa (Forel, 1908). International Journal of Agriculture Innovations and Research 5(1): 118-125.

TRAVAGLINI, R. V., L. E. P. STEFANELLI, A. ARNOSTI, R. S. CAMARGO \& L. C. FORTI, 2017. Isca encapsulada atrativa visando controle microbiano de formigas cortadeiras. Tekhne e Logos 8(3): 100-111.

VIEIRA, A. S., E. D. MORGAN, F. P. DRIJFHOUT \& M. I. CAMARGOMATHIAS, 2012. Chemical composition of metapleuralgland secretions of fungus-growing and non-fungus-growing ants. Journal of Chemical Ecology 38: 1289-1297. DOI: https://doi.org/10.1007/ s10886-012-0185-8.

ZANETTI, R., J. C. ZANUNCIO, J. C. SANTOS, W. L. P. SILVA, G. T. RIBEIRO \& P. G. LEMES, 2014. An overview of integrated management of leaf-cutting ants (Hymenoptera: Formicidae) in Brazilian forest plantations. Forests 5(3): 439-454. DOI: https:// doi.org/10.3390/ 55030439 .

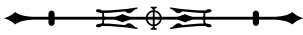


